\title{
Knowledge of health professionals about breastfeeding and factors that lead the weaning: a scoping review
}

\author{
Conhecimento de profissionais de saúde sobre amamentação \\ e fatores que levam ao desmame: uma revisão de escopo
}

Maysa Lannes Duarte (https://orcid.org/0000-0002-8067-2733) ${ }^{1}$

Kairon Ribeiro Dias (https://orcid.org/0000-0002-1146-5503) ${ }^{1}$

Daniele Masterson Tavares Pereira Ferreira (https://orcid.org/0000-0001-7108-1117) ${ }^{2}$

Andréa Fonseca-Gonçalves (https://orcid.org/0000-0001-6467-7078) ${ }^{1}$

\footnotetext{
${ }^{1}$ Departamento de Odontopediatria e Ortodontia, Faculdade de Odontologia, Universidade Federal do Rio de Janeiro. R. Rodolpho Paulo Rocco 325. 21941-913 Rio de Janeiro RJ Brasil.andrea.goncalves@ odonto.ufri.br ${ }^{2}$ Seção de Referência da Biblioteca Central do Centro de Ciências da Saúde, Universidade Federal do Rio de Janeiro. Rio de Janeiro RJ Brasil.
}

\begin{abstract}
This review evaluated the knowledge of health professionals (HP) about breastfeeding and factors that leading the weaning. A search was performed in four electronics databases and the grey literature. The search strategy included Mesh terms and synonyms. No language or date restrictions were adopted. Studies that evaluated the knowledge of HP about breastfeeding and weaning were considered eligible. The studies retrieved by the searches were evaluated by two independently examiners. From 1,417 studies retrieved, 35 were included. Many countries and professionals from different health areas were analyzed. No studies evaluated the dentists' knowledge. Although the included HP know the benefits of breastfeeding for health, the length of breastfeeding recommended by the World Health Organization, exclusive or not, was not aligned with all professionals' endorsement. Information about weaning is scarce; however, HP are mindful of the main potential causes of early weaning. The knowledge of HP is conflicting about breastfeeding and unusual about weaning. Furthermore, no studies were found that presented data on the knowledge of dentists on the subject. Thus, assessments of dentists' knowledge and education measures for HP are necessary since they are frequently questioned about these issues.
\end{abstract}

Key words Breast feeding, Weaning, Health personnel, Health knowledge, Attitudes
Resumo Esta revisão avaliou o conhecimento dos profissionais de saúde (PS) sobre amamentação e fatores que levam ao desmame. Realizou-se buscas em quatro bancos de dados eletrônicos e literatura cinzenta. A estratégia de busca incluiu termos Mesh e sinônimos. Não se adotou restrição de idioma ou data. Estudos avaliando o conhecimento dos PS sobre amamentação e desmame foram elegiveis. Estudos recuperados pelas buscas foram avaliados por dois examinadores independentes. Dos 1.417 estudos recuperados, 35 foram incluídos. Muitos países e PS de diferentes áreas foram analisados. Nenhum estudo avaliou o conhecimento dos dentistas. Embora os PS conheçam os benefícios da amamentação, a duração recomendada pela Organização Mundial da Saúde, exclusiva ou não, não está alinhada com o endosso de todos os PS. Considerando o desmame, a informação é escassa. No entanto, os PS estão atentos às principais causas potenciais do desmame precoce. O conhecimento dos PS é conflitante sobre amamentação e incomum sobre o desmame. Não foram encontrados estudos que apresentassem dados sobre o conhecimento de dentistas sobre a temática. Investigações quanto ao conhecimento dos mesmos e medidas de educação para todos os PS são necessárias, considerando que são frequentemente questionados sobre o tema.

Palavras-chave Aleitamento materno, Desmame, Pessoal de saúde, Conhecimentos, Atitudes 


\section{Introduction}

The American Academy of Pediatrics and the World Health Organization (WHO) recommend that infants receive human milk exclusively for the first six months of life and that breastfeeding continue beyond the first or second year of life as long as a family deems appropriate ${ }^{1}$. Breastfeeding offers numerous health benefits for both the baby and the mother in the short and long term. Exclusive breastfeeding reduces the risk of infant mortality by protecting the baby from infectious and chronic diseases, as well as promoting his sensory and cognitive development ${ }^{2}$.

The term weaning refers to the long transition process in which the child changes from the total dependence on breast milk to the complete interruption of feeding with milk ${ }^{3,4}$. Therefore, weaning begins with the introduction of any food other than breast milk and ends when the baby is fed with milk for the last time. Complementary feeding is the period between these two milestones, that is, the association of other foods together with milk ${ }^{5}$.

Therefore, WHO and United Nations International Children's Emergency Fund (UNICEF) have suggested implementing a program called Ten Steps to Successful Breastfeeding in all institutions providing maternity and newborn services worldwide. The program seeks to support breastfeeding in ten steps, such as ensuring that the professionals involved have sufficient knowledge, competence and skills to support this practice, as well as counseling mothers on the use and risks of feeding using bottles with teats and sucking on pacifiers ${ }^{6}$.

In this context, a multiprofessional team is the ideal, where the dentist, as a health professional, should be included being able to guide the woman on the importance of breastfeeding since there is a strong relationship between natural breastfeeding and the development of the stomatognathic system ${ }^{7}$.

Therefore, knowing the importance of breastfeeding for general health of the baby, this scoping review aimed to evaluate in the available literature the knowledge of health professionals about breastfeeding and weaning, mainly related to exclusive breastfeeding time, weaning age and factors that may be related to early weaning. Thus, this review sought to answer the following question: "What does the literature report about the knowledge of health professionals on breastfeeding and weaning and what are the work areas of these professionals?"

\section{Materials and methods}

This scoping review was developed and conducted following the recommendations of Arksey and O'Malley's ${ }^{8}$ and Levac, Colquhoun and O'Brien'.

\section{Information sources and search strategy}

The search was performed in four electronic databases (PubMed, Lilacs/BBO SciELO and Web of Science) and the grey literature (Open Grey and Trip Database) up to April 2020. The search strategy included the health terminology identified at the Medical Subject Headings (Mesh terms) and synonyms related to the review objective and adapted for each database. There was no language or date limitation. The terms used to construct the strategies were "weaning", "breastfeeding", "health education", "health knowledge, attitudes, practice", "health education", "health knowledge, attitudes, practice", "health personnel" and "allied health personnel". An expert librarian (DMTPF) guided all process of definition of the included terms in the applied search strategy, as well as the search in each database. The combinations of the terms used in each database are described in Chart 1.

\section{Eligibility criteria and selection of studies}

Based on the PCC framework ${ }^{10}$, the inclusion criteria were cross-sectional study, qualitative study, and self-report survey design with humans (P), found by online search strategy (C) to assess the knowledge of health professionals about breastfeeding and weaning as primary or secondary outcomes (C). Two reviewers (MLD and $\mathrm{KRD}$ ) analyzed independently the titles and abstracts of the articles retrieved from searches to identify those potentially eligible for this study. The exclusion criteria were animal and clinical trials studies, literature or systematic reviews, guidelines, editorials, letters to the editor, studies with health students and/or professionals from areas different of health, studies about mother's knowledge, studies that assessed knowledge after an intervention and studies that did not cover the topic relevant to the review objective. If some abstract did not provide enough information for a definite decision, full articles were evaluated. Uncertainties about inclusion were discussed with a third reviewer (AFG), who had read the respective titles and abstracts. Studies available in more than one database were considered only once. Finally, a hand search was performed in 
Chart 1. Descriptors and their combinations of search strategy in each database.

\begin{tabular}{|c|c|}
\hline $\begin{array}{l}\text { Electronic } \\
\text { databases }\end{array}$ & Search strategy \\
\hline PubMed & $\begin{array}{l}\text { ((weaning }[\mathrm{mh}]) \text { OR (weaning[tiab]) OR (breastfeeding }[\mathrm{mh}]) \text { OR (breastfeeding }[\text { tiab }])) \\
\text { AND }((\text { health education }[\mathrm{mh}]) \text { OR (health knowledge, attitudes, practice[mh]) OR } \\
\text { (health education }[\text { tiab]) OR (health knowledge, attitudes, practice }[\text { tiab])) AND }((\text { health } \\
\text { personnel[mh]) OR (health personnel[tiab]) OR (allied health personnel[mh]) OR (allied } \\
\text { health personnel[tiab]) OR (health professionals }[\text { tiab])) }\end{array}$ \\
\hline LILACS e BBO & $\begin{array}{l}\text { (mh:(weaning)) OR (tw:(weaning)) OR (mh:(breastfeeding)) OR (tw:(breastfeeding)) AND } \\
\text { (mh:(health education)) OR (mh:(health knowledge, attitudes, practice)) OR (tw:(health } \\
\text { education)) OR (tw:(health knowledge, attitudes, practice)) AND (mh:(health personnel)) } \\
\text { OR (tw:(health personnel)) OR (mh:(allied health personnel)) OR (tw:(allied health } \\
\text { personnel)) OR (tw:(health professionals)) }\end{array}$ \\
\hline SciELO & $\begin{array}{l}\text { ((subject:weaning) OR (subject:breastfeeding)) AND ((subject:health education) OR } \\
\text { (subject:health knowledge, attitudes, practice)) AND ((subject:health personnel) OR } \\
\text { (subject:allied health personnel) OR (subject:health professionals)) }\end{array}$ \\
\hline Web of Science & $\begin{array}{l}\text { \#3 AND \#2 AND \#1 } \\
\# 3 \\
\text { TS=(“health personnel" OR “allied health personnel" OR "health professionals") } \\
\# 2 \\
\text { TS=(“health education" OR "health knowledge, attitudes, practice") } \\
\# 1 \\
\text { TS=(weaning OR breastfeeding) }\end{array}$ \\
\hline Open Grey & $\begin{array}{l}\text { (weaning OR breastfeeding) AND ("health education" OR "health knowledge, attitudes, } \\
\text { practice") AND ("health personnel” OR "allied health personnel" OR "health professionals") }\end{array}$ \\
\hline Trip Database & $\begin{array}{l}\text { (weaning OR breastfeeding) AND ("health education" OR "health knowledge, attitudes, } \\
\text { practice") AND ("health personnel" OR "allied health personnel" OR "health professionals") }\end{array}$ \\
\hline
\end{tabular}

Source: Authors.

the reference list of the included studies. When the full texts were not available, the authors were contacted by e-mail and the research gate website (eight articles were requested by this means). The EndNote website was used for literature management.

\section{Data extraction}

Data extracted of the included studies were: characterization of the study (authors, year of publication and country), study design (cross-sectional, qualitative study and self-report survey design), sample (professional category and number of participants), methodology used (questionnaires or others) and main results (exclusive or not exclusive breastfeeding, exclusive and combined breastfeeding time and factors that lead to weaning and others results). When these data were not available in the full texts, the authors were contacted by e-mail and the research gate website. The data collected were analyzed descriptively.

\section{Results}

\section{Study selection}

Figure 1 presents the flow diagram with the search process. A total of 1,417 studies were identified and 1,362 records remained after the removal of duplicates using the reference manager website. Posteriorly, another 1,310 studies were removed after their titles and abstracts have been evaluated because they did not meet the inclusion criteria. Fifty-two full texts were read and 17 were excluded due to not fulfilling the inclusion criteria. The reasons for the exclusions are described in Figure 1. Ultimately, 35 studies were included in this scoping review.

\section{Study characteristics}

Chart 2 shows the characteristics of the 35 included studies in this scoping review. The articles were published between 1984 to 2019 . Twelve studies were carried out in the United 


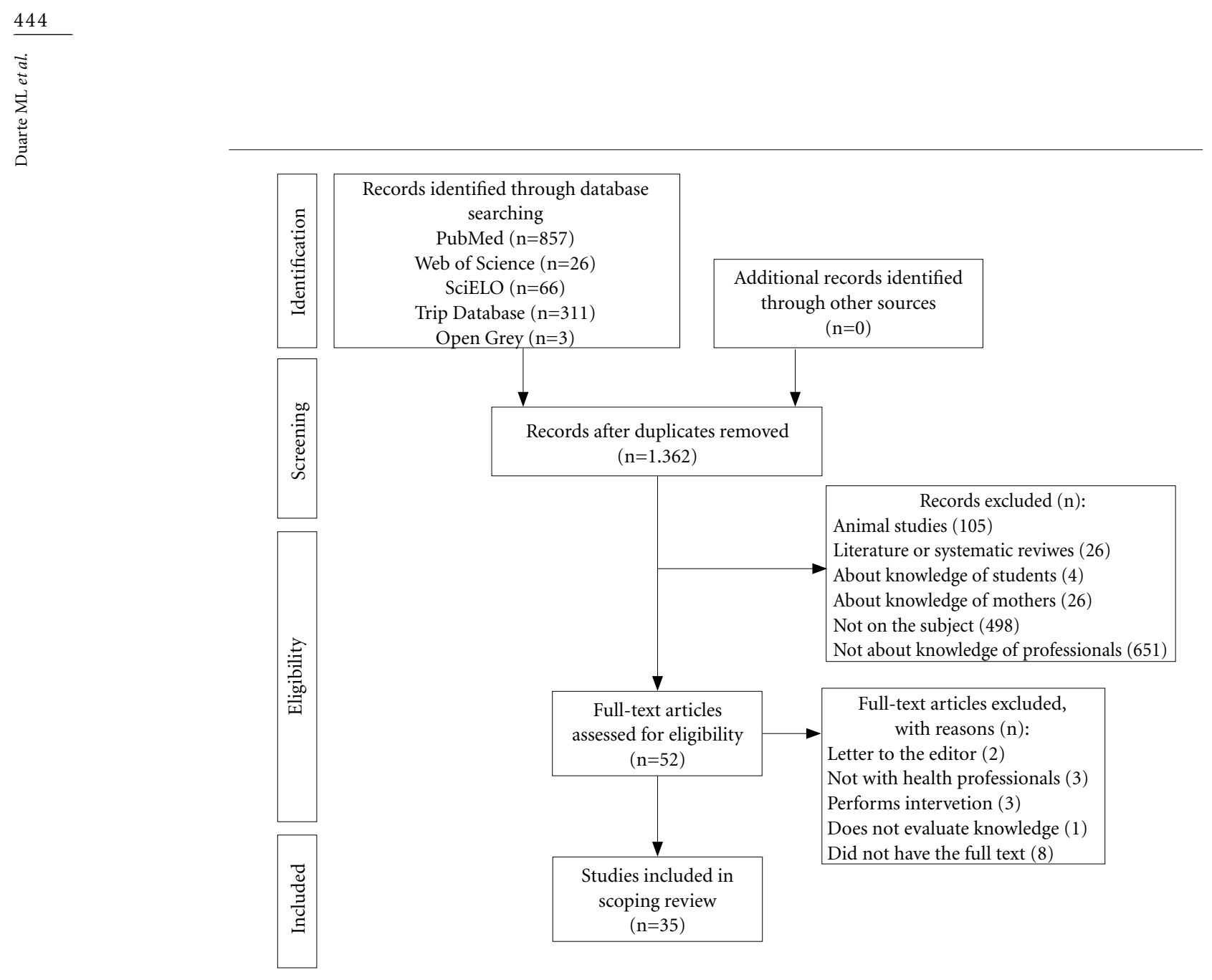

Figure 1. Flow diagram of databases searched according to PRISMA guidelines.

Source: Authors.

States of America (USA), four in Brazil, two in Australia, two in Turkey, two in Pakistan and two in Puerto Rico. The other countries that carried out a study were China, Sweden, Chile, Norway, Egypt, France, Lithuania, Iraq, Nigeria, England and India. The articles were written in four languages, English, Portuguese, Spanish, French and Chinese.

Twenty-six cross-sectional studies, five qualitative studies, two descriptive studies, one self-report design and one exploratory study were selected. Questionnaires were used by 27 studies as a method of assessing knowledge, the number of questions ranged from 10 to 139 . The other forms of evaluation were interviews and focus groups, chosen by six and two studies, respectively.

A total of 43,579 health professionals were investigated. Of these, 4542 were nurses, 1763 were doctors, 893 midwives, 177 nutritionists, 119 nursing technicians, 99 paramedics, 65 health educators, 29 pharmacists, 23 community health agents, 12 medical office assistants and 1 dental assistant. In four studies, the professional category was not described and one study did not differ the number of nurses from the number of midwives, totaling 35,809 professionals. No studies that evaluate dentists' knowledge were found.

When the knowledge about breastfeeding was investigated in general - such as the benefits, the difference between the formula used, importance of colostrum - four studies reported a high knowledge level related to breastfeeding ${ }^{11-14}$. Other studies reported regular knowledge level ${ }^{15-17}$ or good knowledge level ${ }^{18}$ for most of the investigated sample. With regard to the benefits of breastfeeding, the professionals cited: best source of nutrition for babies ${ }^{19-22}$, protection against infections in babies , $^{19,23-26}$, increased immune function $^{23-25}$, prevention of maternal diseases - such as breast cancer $^{27,28}$, increased emotional bond between mother and child ${ }^{28}$, be convenient ${ }^{22}$ and that it is a cheap food ${ }^{19,22,28}$. 
Chart 2. Description of the included studies.

\begin{tabular}{|c|c|c|c|c|c|}
\hline $\begin{array}{c}\text { Author } \\
\text { (year) }\end{array}$ & Country & $\begin{array}{l}\text { Study } \\
\text { design }\end{array}$ & Sample & $\begin{array}{c}\text { Methodology } \\
\text { used }\end{array}$ & Main results \\
\hline $\begin{array}{l}\text { Xian et al. } \\
(2019)\end{array}$ & China & $\begin{array}{l}\text { Cross- } \\
\text { sectional } \\
\text { study }\end{array}$ & $\begin{array}{l}35.243 \text { health } \\
\text { professionals }\end{array}$ & Questionnaire & $\begin{array}{l}75.3 \% \text { of the respondents had a high rate of } \\
\text { knowledge about breastfeeding. The rate of } \\
\text { knowledge about exclusive breastfeeding was high } \\
(86.7 \%)\end{array}$ \\
\hline $\begin{array}{l}\text { Alakaam et } \\
\text { al. }(2018)\end{array}$ & USA & $\begin{array}{l}\text { Self-report } \\
\text { survey } \\
\text { design }\end{array}$ & 302 nurses & Questionnaire & $\begin{array}{l}\text { Total knowledge scores ranged between } 19 \text { and } 39 \\
\text { in the overall sample, with the mean score } 32,75 \text {. } \\
33 \text { respondents (10.9\%) earned a perfect score to } \\
\text { breastfeeding knowledge. When questioned "When } \\
\text { Should the Mother Stop Breastfeeding?" } 46.7 \% \text { of } \\
\text { nurses answered in cases of breast abscess, } 34.1 \% \text { in } \\
\text { cases of mastitis and } 30.8 \% \text { in cases of the baby have } \\
\text { frequent loose stools }\end{array}$ \\
\hline $\begin{array}{l}\text { Melin, } \\
\text { Björklund } \\
\text { and } \\
\text { Zwedberg } \\
(2018)\end{array}$ & Sweden & $\begin{array}{l}\text { Qualitative } \\
\text { study }\end{array}$ & 12 pediatricians & $\begin{array}{l}\text { Individual } \\
\text { semi- } \\
\text { structured } \\
\text { interviews }\end{array}$ & $\begin{array}{l}\text { All pediatricians agreed that they played an } \\
\text { important role in promoting breastfeeding and } \\
\text { believed that they possessed excellent understanding } \\
\text { of when supplemental feeding was necessary. Several } \\
\text { factors have been described as influencing mothers' } \\
\text { decisions to not breastfeed or discontinue after a } \\
\text { few months, including mental health conditions, } \\
\text { breast surgeries, the use of prescription drugs, } \\
\text { social situations and socioeconomic conditions } \\
\text { (lower breastfeeding rates in low-income areas). } \\
\text { Respondents thought that breastfeeding for } \\
\text { more than one year was not compatible with the } \\
\text { predominant current lifestyle }\end{array}$ \\
\hline $\begin{array}{l}\text { Holtzman } \\
\text { and } \\
\text { Usherwood } \\
(2018)\end{array}$ & Australian & $\begin{array}{l}\text { Qualitative } \\
\text { study }\end{array}$ & $\begin{array}{l}10 \text { general } \\
\text { practitioners } \\
(\mathrm{GP})\end{array}$ & $\begin{array}{l}\text { Semi- } \\
\text { structured } \\
\text { interviews }\end{array}$ & $\begin{array}{l}\text { GPs interviewed felt that the decision to wean was } \\
\text { an individual one. Only one GP mentioned the } \\
\text { Australian National Health and Medical Research } \\
\text { Council guidelines, which recommend exclusive } \\
\text { breastfeeding up to } 6 \text { months and continuation of } \\
\text { breastfeeding for at least } 12 \text { months. One GP stated } \\
\text { that he recommends mothers to wean if the baby } \\
\text { bites while breastfeeding. Some GP were supportive } \\
\text { extended breastfeeding (beyond the age of } 2 \text { years) } \\
\text { and others had quite negative views about it }\end{array}$ \\
\hline $\begin{array}{l}\text { Marambio, } \\
\text { Benadof } \\
\text { and Huerta } \\
(2017)\end{array}$ & Chile & $\begin{array}{l}\text { Cross- } \\
\text { sectional } \\
\text { study }\end{array}$ & $\begin{array}{l}78 \text { health } \\
\text { professionals } \\
\text { (midwives, } \\
\text { doctors, } \\
\text { nurses and } \\
\text { nutritionists) }\end{array}$ & $\begin{array}{l}\text { Questionnaire } \\
\text { with } 22 \\
\text { questions }\end{array}$ & $\begin{array}{l}42.2 \% \text { were correct between } 50 \text { and } 67 \% \text { of the } \\
\text { questions correctly (regular knowledge), } 29.5 \% \text { were } \\
\text { correct } 75 \% \text { (very good knowledge), } 24.4 \% \text { were } \\
\text { correct between } 68 \text { to } 74 \% \text { (good knowledge). Only } \\
3.8 \% \text { of the participants answered less than } 50 \% \\
\text { correctly, being all these doctors. Most nutritionists, } \\
\text { midwives and nurses demonstrated knowledge } \\
\text { classified as very good or good. } 65.4 \% \text { of doctors } \\
\text { were classified as having regular knowledge }\end{array}$ \\
\hline $\begin{array}{l}\text { Svendby et } \\
\text { al. (2017) }\end{array}$ & Norway & $\begin{array}{l}\text { Cross- } \\
\text { sectional } \\
\text { study }\end{array}$ & $\begin{array}{l}69 \text { general } \\
\text { practitioners } \\
\text { (GPs) }\end{array}$ & Questionnaire & $\begin{array}{l}39 \% \text { of professionals recommend exclusive } \\
\text { breastfeeding for } 6 \text { months and } 44 \% \text { recommend } \\
\text { that the child be breastfed only up to a maximum } \\
\text { of } 12 \text { months. } 26 \% \text { stated correctly that formula } \\
\text { and human milk differ with respect to nourishment } \\
\text { and long-term health effects. } 42 \% \text { of GPs } \\
\text { considered maternal HIV infection to represent a } \\
\text { contraindication for breastfeeding }\end{array}$ \\
\hline
\end{tabular}


Chart 2. Description of the included studies.

\begin{tabular}{|c|c|c|c|c|c|}
\hline $\begin{array}{c}\text { Author } \\
\text { (year) }\end{array}$ & Country & $\begin{array}{l}\text { Study } \\
\text { design }\end{array}$ & Sample & $\begin{array}{c}\text { Methodology } \\
\text { used }\end{array}$ & Main results \\
\hline $\begin{array}{l}\text { Artantas et } \\
\text { al. }(2016)\end{array}$ & Turkey & $\begin{array}{l}\text { Cross- } \\
\text { sectional } \\
\text { study }\end{array}$ & $\begin{array}{l}25 \text { gynecology } \\
\text { and obstetrics, } \\
11 \text { pediatrics, } 64 \\
\text { family medicine, } \\
74 \text { general } \\
\text { practitioners, } 447 \\
\text { midwife-nurse }\end{array}$ & $\begin{array}{l}\text { Questionnaire } \\
\text { with } 29 \\
\text { questions }\end{array}$ & $\begin{array}{l}\text { Most participants }(94.9 \%) \text { recommended exclusive } \\
\text { breastfeeding for the first } 6 \text { months of age. For } \\
\text { the period after the initiation of complementary } \\
\text { food, } 84.8 \% \text { were suggesting the continuation of } \\
\text { breastfeeding until } 2 \text { nd year of age and } 10.1 \% \\
\text { suggested breastfeeding until one year of age. } 59.9 \% \\
\text { of the participants declared that breast milk would } \\
\text { not be enough for twin babies and formula shall be } \\
\text { used }\end{array}$ \\
\hline $\begin{array}{l}\text { Dias et al. } \\
(2016)\end{array}$ & Brazil & $\begin{array}{l}\text { Qualitative } \\
\text { study }\end{array}$ & 8 nurses & $\begin{array}{l}\text { Semi- } \\
\text { structured } \\
\text { interviews }\end{array}$ & $\begin{array}{l}\text { Most participants reported that one of the advantages } \\
\text { breastfeeding for the family, prevention and } \\
\text { promotion of child and maternal health, through the } \\
\text { prevention of maternal and child diseases. Another } \\
\text { advantage very emphasized by most nurses was } \\
\text { the increase in emotional bonds between mother } \\
\text { and child and family, as well as family unity and } \\
\text { increased bonding. In addition, nurses highlighted } \\
\text { the economics and practicality of breastfeeding as an } \\
\text { advantage }\end{array}$ \\
\hline $\begin{array}{l}\text { Sims et al. } \\
(2015)\end{array}$ & USA & $\begin{array}{l}\text { Cross- } \\
\text { sectional } \\
\text { study }\end{array}$ & 29 doctors & $\begin{array}{l}\text { Questionnaire } \\
\text { with } 33 \\
\text { questions }\end{array}$ & $\begin{array}{l}\text { The identified barriers to exclusive breastfeeding } \\
\text { included families not being well informed }(62 \%) \text {, } \\
\text { families wanting formula ( } 55 \%) \text {, inadequate } \\
\text { lactation consultation ( } 38 \%) \text {, recommendation } \\
\text { for formula by nurses }(35 \%) \text {, nursing staff } \\
\text { not encouraging breastfeeding ( } 35 \%) \text {, doctors } \\
\text { not encouraging breastfeeding }(21 \%) \text { and } \\
\text { recommendation for formula by neonatologist }(7 \%)\end{array}$ \\
\hline $\begin{array}{l}\text { Fonseca- } \\
\text { Machado et } \\
\text { al. (2014) }\end{array}$ & Brazil & $\begin{array}{l}\text { Cross- } \\
\text { sectional } \\
\text { study }\end{array}$ & $\begin{array}{l}45 \text { nurses and } \\
40 \text { nursing } \\
\text { technicians }\end{array}$ & $\begin{array}{l}\text { Semi- } \\
\text { structured } \\
\text { questionnaire }\end{array}$ & $\begin{array}{l}48.2 \% \text { of participants believe that, if the is milk } \\
\text { letdown up to three days after delivery it is necessary } \\
\text { to initiate food supplementation and } 44.7 \% \\
\text { disagree this affirmation. If the production of milk } \\
\text { is decreased and the baby shows to be hungry, } \\
24.7 \% \text { believe that supplementation should start } \\
\text { immediately }\end{array}$ \\
\hline $\begin{array}{l}\text { Sallam et al. } \\
\text { (2013) }\end{array}$ & Egypt & $\begin{array}{l}\text { Qualitative } \\
\text { study }\end{array}$ & $\begin{array}{l}30 \text { women } \\
\text { healthcare } \\
\text { workers }(15 \\
\text { nurses, } 15 \\
\text { doctors) }\end{array}$ & $\begin{array}{l}\text { Oral } \\
\text { interviews }\end{array}$ & $\begin{array}{l}\text { Respondents had good knowledge about importance } \\
\text { of early breastfeeding initiation, as } 96.7 \% \text { were aware } \\
\text { of the benefits of colostrum and } 93.3 \% \text { of them } \\
\text { had a positive attitude regarding early breastfeeding } \\
\text { initiation being right for each baby }\end{array}$ \\
\hline $\begin{array}{l}\text { Schaffar et } \\
\text { al. }(2012)\end{array}$ & France & $\begin{array}{l}\text { Cross- } \\
\text { sectional } \\
\text { study }\end{array}$ & 29 pharmacists & $\begin{array}{l}\text { Questionnaire } \\
\text { with } 26 \\
\text { questions }\end{array}$ & $\begin{array}{l}\text { The WHO recommendation for the duration } \\
\text { of exclusive breastfeeding was known by } 55 \% \\
\text { of pharmacists. In cases of breast clefts, } 90 \% \\
\text { of pharmacists advised the continuation of } \\
\text { breastfeeding and } 10 \% \text { advised that the position } \\
\text { of the baby in the breast be corrected. For mastitis, } \\
\text { the first attitude of pharmacists was to direct the } \\
\text { mother to a doctor ( } 38 \% \text { ). Faced with a woman } \\
\text { complaining of insufficient lactation, none of } \\
\text { the participants responded to advise stopping } \\
\text { breastfeeding. About the factors that contraindicate } \\
\text { breastfeeding, pharmacists pointed to infection by } \\
\text { the human immunodeficiency virus (HIV) (62\%), } \\
\text { active tuberculosis (48\%) and the child's galactosemia } \\
\text { ( } 31 \% \text { ) }\end{array}$ \\
\hline
\end{tabular}


Chart 2. Description of the included studies.

\begin{tabular}{|c|c|c|c|c|c|}
\hline $\begin{array}{c}\text { Author } \\
\text { (year) }\end{array}$ & Country & $\begin{array}{l}\text { Study } \\
\text { design }\end{array}$ & Sample & $\begin{array}{c}\text { Methodology } \\
\text { used }\end{array}$ & Main results \\
\hline $\begin{array}{l}\text { McLaughlin } \\
\text { et al. (2011) }\end{array}$ & Australian & $\begin{array}{l}\text { Cross- } \\
\text { sectional } \\
\text { study }\end{array}$ & $\begin{array}{l}241 \text { pediatric } \\
\text { nurses }\end{array}$ & $\begin{array}{l}\text { Questionnaire } \\
\text { with } 139 \text { items }\end{array}$ & $\begin{array}{l}97 \% \text { knew the benefits of breast milk for the baby. } \\
\text { Some believed infant formula is a nutritional } \\
\text { equivalent to breastmilk and a number were } \\
\text { unaware that supplemental formulas can interfere } \\
\text { with the success of breastfeeding. } 26 \% \text { of } \\
\text { respondents did not agree breastfeeding should } \\
\text { continue until two years of age and beyond and } \\
19 \% \text { were unsure. } 85 \% \text { of participants replied that } \\
\text { mothers should not stop breastfeeding when infant } \\
\text { is teething. } 25 \% \text { of participants indicated that they } \\
\text { would recommend ceasing breastfeeding in response } \\
\text { to maternal fatigue }\end{array}$ \\
\hline $\begin{array}{l}\text { Hanif et al. } \\
(2010)\end{array}$ & Pakistan & $\begin{array}{l}\text { Cross- } \\
\text { sectional } \\
\text { study }\end{array}$ & $\begin{array}{l}197 \text { doctors and } \\
99 \text { paramedics }\end{array}$ & Questionnaire & $\begin{array}{l}100 \% \text { of doctors and paramedics agreed that breast } \\
\text { milk is beneficial for baby and } 85 \% \text { of doctors } \\
\text { pointed as advantage of breastfeeding the protection } \\
\text { against infection. } 49.7 \% \text { of doctors believe that } \\
\text { weaning with the introduction of food in addition } \\
\text { to breastfeeding should be at } 6 \text { months, while } \\
30.0 \% \text { believe that it should be at } 4 \text { months. } 70.0 \% \\
\text { of doctors believe that breastfeeding should be } \\
\text { continued for } 24 \text { months }\end{array}$ \\
\hline $\begin{array}{l}\text { Leavitt et al. } \\
\text { (2009) }\end{array}$ & $\begin{array}{l}\text { Puerto } \\
\text { Rico }\end{array}$ & $\begin{array}{l}\text { Cross- } \\
\text { sectional } \\
\text { study }\end{array}$ & $\begin{array}{l}111 \text { pediatricians, } \\
48 \text { gynecologists, } \\
11 \text { family } \\
\text { medicine, } 7 \text { other } \\
\text { specialty }\end{array}$ & $\begin{array}{l}\text { Questionnaire } \\
\text { with } 20 \\
\text { questions }\end{array}$ & $\begin{array}{l}74 \% \text { of doctors recommended exclusive } \\
\text { breastfeeding to their patients, while } 19 \% \text { advising } \\
\text { a combination of formula and breast milk. } 61 \% \\
\text { recommended breastfeeding for at least } 6 \text { months } \\
\text { and } 24 \% \text { for the length of time the mother prefers. } \\
44 \% \text { will recommend starting breastfeeding during } \\
\text { the first hour after birth and } 38 \% \text { as early as the } \\
\text { mothers wants to. Doctors were asked about } \\
\text { contraindications to breastfeeding responding: the } \\
\text { use of illicit drugs ( } 94 \%), \text { HIV (93\%), Hepatitis B } \\
\text { e C (57\% e } 55 \%), \text { breast abscess }(55 \%) \text {, mastitis } \\
\text { (22\%) and cracked nipples (15\%). Infants' } \\
\text { contraindications to breastfeeding included: } \\
\text { galactosemia }(72 \%) \text { and jaundice (16\%) }\end{array}$ \\
\hline $\begin{array}{l}\text { Levinienè et } \\
\text { al. (2009) }\end{array}$ & Lithuania & $\begin{array}{l}\text { Cross- } \\
\text { sectional } \\
\text { study }\end{array}$ & $\begin{array}{l}84 \text { general } \\
\text { practitioners } \\
(\mathrm{GP}) \text { and } 52 \\
\text { nurses }\end{array}$ & Questionnaire & $\begin{array}{l}51 \% \text { of GP and } 45 \% \text { of nurses recommended } \\
\text { mothers to give additional liquids between } \\
\text { breastfeeding of an infant and } 1 / 3 \text { of health care } \\
\text { professionals recommended mothers to give } \\
\text { complementary food for infants before } 6 \text { months } \\
\text { of age. Only } 21.6 \% \text { of GP and } 27.5 \% \text { of nurses } \\
\text { knew that breastfeeding accompanied with } \\
\text { complementary food should be continued until the } \\
\text { age of } 2 \text { years and longer }\end{array}$ \\
\hline $\begin{array}{l}\text { Marques et } \\
\text { al. (2009) }\end{array}$ & Brazil & $\begin{array}{l}\text { Cross- } \\
\text { sectional } \\
\text { study }\end{array}$ & $\begin{array}{l}2 \text { doctors, } 3 \\
\text { nurses, } 2 \text { nursing } \\
\text { technicians, } \\
1 \text { dental } \\
\text { assistant and } 1 \\
\text { nutritionist and } \\
23 \text { community } \\
\text { health workers }\end{array}$ & $\begin{array}{l}\text { Semi- } \\
\text { structured } \\
\text { interviews and } \\
\text { focus group }\end{array}$ & $\begin{array}{l}82.4 \% \text { reported not having received any specific } \\
\text { course on breastfeeding. It was observed that the } \\
\text { act of breastfeeding was considered important for } \\
\text { the baby. When asked if they considered themselves } \\
\text { capable of guiding mothers on the correct lactation } \\
\text { practice, health professionals pointed out the need } \\
\text { for training. Moreover, the knowledge passed on by } \\
\text { professionals to mothers was obtained through their } \\
\text { experience, as a mother, or through the observation } \\
\text { of mothers in the community in which they live } \\
\text { and/or work }\end{array}$ \\
\hline
\end{tabular}


Chart 2. Description of the included studies.

\begin{tabular}{|c|c|c|c|c|c|}
\hline $\begin{array}{c}\text { Author } \\
\text { (year) }\end{array}$ & Country & $\begin{array}{l}\text { Study } \\
\text { design }\end{array}$ & Sample & $\begin{array}{c}\text { Methodology } \\
\text { used }\end{array}$ & Main results \\
\hline $\begin{array}{l}\text { Silvestre et } \\
\text { al. (2009) }\end{array}$ & Brazil & $\begin{array}{l}\text { Cross- } \\
\text { sectional } \\
\text { Study }\end{array}$ & $\begin{array}{l}55 \text { nurses and } 34 \\
\text { doctors }\end{array}$ & $\begin{array}{l}\text { Structured } \\
\text { questionnaire } \\
\text { with open } \\
\text { and closed } \\
\text { questions }\end{array}$ & $\begin{array}{l}77.5 \% \text { of respondents advise maintaining exclusive } \\
\text { breastfeeding when mothers work outside the home. } \\
72.5 \% \text { advise against formula if the baby is healthy. } \\
\text { Less than half of the participants pointed out that } \\
\text { infant formula should be offered immediately } \\
\text { to children who show signs of hunger, slight } \\
\text { deceleration in weight gain, who show no support } \\
\text { on the 3rd postpartum day or when the mother will } \\
\text { return to work in the } 3 \text { rd month after-birth. } 92.1 \% \text { of } \\
\text { participants indicated } 6 \text { months as the ideal duration } \\
\text { of exclusive breastfeeding. About the duration of } \\
\text { breastfeeding } 83.1 \% \text { of the participants considered } \\
\text { that it should be for } 24 \text { months or more }\end{array}$ \\
\hline $\begin{array}{l}\text { Szucs, } \\
\text { Miracle and } \\
\text { Rosenman } \\
(2009)\end{array}$ & USA & $\begin{array}{l}\text { Qualitative } \\
\text { study }\end{array}$ & $\begin{array}{l}36 \text { HPs (pediatric } \\
\text { and obstetric } \\
\text { doctors; pediatric, } \\
\text { obstetric, } \\
\text { public health } \\
\text { and telephone } \\
\text { triage answering } \\
\text { service nurses; } \\
\text { WIC personnel } \\
\text { and inpatient } \\
\text { lactation } \\
\text { consultants) }\end{array}$ & Focus groups & $\begin{array}{l}\text { Cultures and attitudes shaped widely divergent } \\
\text { views among providers toward breastfeeding in } \\
\text { public and duration of breastfeeding. In all of the } \\
\text { non-doctors focus groups, there were examples in } \\
\text { which providers' personal breastfeeding experiences } \\
\text { led to advice for women that was contrary to } \\
\text { evidence-based recommendations. Specific examples } \\
\text { included advice about use of early pacifier, duration } \\
\text { of breastfeeding, exclusivity of breastfeeding, or } \\
\text { normal weight loss in the postpartum period }\end{array}$ \\
\hline $\begin{array}{l}\text { Karaçam } \\
\text { and Kitis } \\
(2005)\end{array}$ & Turkey & $\begin{array}{l}\text { Cross- } \\
\text { sectional } \\
\text { study }\end{array}$ & $\begin{array}{l}301 \text { midwives } \\
\text { and nurses }\end{array}$ & $\begin{array}{l}\text { Questionnaire } \\
\text { with } 22 \\
\text { questions }\end{array}$ & $\begin{array}{l}61.1 \% \text { midwives and nurses recommended that } \\
\text { babies should be exclusively breast fed for } 6 \text { months } \\
\text { and } 33.9 \% \text { reported that exclusive breast feeding } \\
\text { for } 4-6 \text { months would be appropriate. } 95.0 \% \\
\text { participants gave one or more situations to feed } \\
\text { babies with artificial milk before } 6 \text { months, such } \\
\text { as: insufficient weight gain of the babies, maternal } \\
\text { conditions, lack of breast milk, baby conditions, } \\
\text { working mothers and premature babies or low birth } \\
\text { weight. } 47.5 \% \text { of the participants recommended } \\
\text { that breast milk should be collected when } \\
\text { mothers resumed working and } 26.6 \% \text { reported } \\
\text { recommending that breast milk should be expressed } \\
\text { but added that artificial milk could be given }\end{array}$ \\
\hline $\begin{array}{l}\text { Al-Nassaj, } \\
\text { Al-Ward } \\
\text { and Al- } \\
\text { Awqati } \\
\text { (2004) }\end{array}$ & Iraq & $\begin{array}{l}\text { Cross- } \\
\text { sectional } \\
\text { study }\end{array}$ & $\begin{array}{l}75 \text { resident } \\
\text { doctors (RDs) } \\
\text { and } 50 \text { general } \\
\text { practitioners } \\
\text { (GPs) }\end{array}$ & $\begin{array}{l}\text { Questionnaire } \\
\text { with } 50 \text { items }\end{array}$ & $\begin{array}{l}\text { GPs had the most positive attitudes towards } \\
\text { breastfeeding when asked "What do you prefer for } \\
\text { feeding your baby in the future?" } 86.0 \% \text { thought } \\
\text { breastfeeding was the preferred type of infant feeding } \\
\text { compared with only } 57.3 \% \text { of RDs. } 49.3 \% \text { of RDs } \\
\text { agreed they would encourage a working mother to } \\
\text { breastfeed her baby in her workplace compared with } \\
60.0 \% \text { of GPs. Scores on knowledge and problem- } \\
\text { solving approaches towards breastfeeding were } \\
\text { slightly higher among GP (50.0\% of GP and } 45.3 \% \\
\text { of RDs had adequate knowledge) }\end{array}$ \\
\hline
\end{tabular}


Chart 2. Description of the included studies.

\begin{tabular}{|c|c|c|c|c|c|}
\hline $\begin{array}{c}\text { Author } \\
\text { (year) }\end{array}$ & Country & $\begin{array}{l}\text { Study } \\
\text { design }\end{array}$ & Sample & $\begin{array}{c}\text { Methodology } \\
\text { used }\end{array}$ & Main results \\
\hline $\begin{array}{l}\text { Hellings et } \\
\text { al. (2004) }\end{array}$ & USA & $\begin{array}{l}\text { Cross- } \\
\text { sectional } \\
\text { study }\end{array}$ & $\begin{array}{l}95 \text { pediatric } \\
\text { nurse } \\
\text { practitioners } \\
(\mathrm{PNP})\end{array}$ & Questionnaire & $\begin{array}{l}90.8 \% \text { would encourage more frequent breastfeeding } \\
\text { when there was concern regarding the mother's milk } \\
\text { supply in the first two weeks, whereas only } 1.3 \% \\
\text { would supplement with glucose and } 0.3 \% \text { would } \\
\text { supplement with formula. } 88.2 \% \text { recommended } \\
\text { increased breastfeeding when the concern was } \\
\text { jaundice in an otherwise healthy } 4 \text {-day-old infant, } \\
\text { however, while } 5.5 \% \text { would supplement with glucose } \\
\text { water and } 1.3 \% \text { would supplement with formula. } \\
96.1 \% \text { would not stop breastfeeding in a patient } \\
\text { with mastitis or in the presence of concern over } \\
\text { milk supply, } 100 \% \text { would not stop because the baby } \\
\text { was teething, } 98.7 \% \text { would not stop if the baby was } \\
\text { having frequent loose stools, and } 97.4 \% \text { would not } \\
\text { recommend the cessation of breastfeeding if the baby } \\
\text { did not seem satiated. Only with a breast abscess was } \\
\text { there increased uncertainty about management }\end{array}$ \\
\hline $\begin{array}{l}\text { Spear } \\
(2004)\end{array}$ & USA & $\begin{array}{l}\text { Descriptive } \\
\text { study }\end{array}$ & 151 nurses & Questionnaire & $\begin{array}{l}88.0 \% \text { of the participants agreed that adolescent } \\
\text { mother's ought to be encouraged to breastfeed and } \\
\text { only } 11.9 \% \text { of the participants indicated that they } \\
\text { did not agree with this statement. A few participants } \\
\text { were somewhat skeptical about the ability of } \\
\text { adolescents to successfully breastfeed because to the } \\
\text { issue of developmental stage and maturity. } 41.1 \% \text { of } \\
\text { nurses did not know there are nutritional differences } \\
\text { between breast milk and infant formula }\end{array}$ \\
\hline $\begin{array}{l}\text { Okolo and } \\
\text { Ogbonna } \\
(2002)\end{array}$ & Nigeria & $\begin{array}{l}\text { Cross- } \\
\text { sectional } \\
\text { study }\end{array}$ & $\begin{array}{l}6 \text { doctors and } \\
160 \text { nurses }\end{array}$ & $\begin{array}{l}\text { Structured } \\
\text { interviewer } \\
\text { questionnaire }\end{array}$ & $\begin{array}{l}23.1 \% \text { nurses believe babies less than six months } \\
\text { should not be given water. Less than } 50 \% \text { of each } \\
\text { professional category believes complementary } \\
\text { feeding should start at } 6 \text { months }\end{array}$ \\
\hline $\begin{array}{l}\text { Hellings } \\
\text { and Howe } \\
(2000)\end{array}$ & USA & $\begin{array}{l}\text { Cross- } \\
\text { sectional } \\
\text { study }\end{array}$ & 405 nurses & Questionnaire & $\begin{array}{l}90.1 \% \text { would encourage more frequent } \\
\text { breastfeeding when there was concern regarding } \\
\text { the mother's milk supply, } 1.3 \% \text { would supplement } \\
\text { with glucose and } 0.3 \% \text { would supplement with } \\
\text { formula. No respondent recommended the cessation } \\
\text { of breastfeeding. } 81.5 \% \text { recommended increased } \\
\text { breastfeeding when the concern was jaundice, } \\
11.5 \% \text { would supplement with glucose and } 0.3 \% \\
\text { would supplement with formula. } 91.4 \% \text { would } \\
\text { not stop breastfeeding in a patient with mastitis, } \\
95.8 \% \text { would not stop in the presence of concern } \\
\text { over milk supply, } 94.6 \% \text { said no in the presence of } \\
\text { a teething baby, } 95.1 \% \text { would not stop if the baby } \\
\text { was having frequent loose stools, and } 95.6 \% \text { would } \\
\text { not recommend the cessation of breastfeeding if } \\
\text { the baby did not seem satiated. Only with a breast } \\
\text { abscess was there uncertainty }\end{array}$ \\
\hline $\begin{array}{l}\text { Rasheed, } \\
\text { Siddiqui } \\
\text { and Baig } \\
(2000)\end{array}$ & Pakistan & $\begin{array}{l}\text { Cross- } \\
\text { sectional } \\
\text { study }\end{array}$ & $\begin{array}{l}70 \text { nurses (16 } \\
\text { qualified and } 54 \\
\text { non-qualified) }\end{array}$ & Questionnaire & $\begin{array}{l}58.55 \% \text { recommended the introduction of a bottle } \\
\text { from the first day, while } 28.57 \% \text { said that it should } \\
\text { not be administered. } 27 \text { professionals would not } \\
\text { indicate continuation of breastfeeding when the } \\
\text { mother had a nipple flap and } 40 \text { when the baby had } \\
\text { diarrhea }\end{array}$ \\
\hline
\end{tabular}


Chart 2. Description of the included studies.

\begin{tabular}{|c|c|c|c|c|c|}
\hline $\begin{array}{c}\text { Author } \\
\text { (year) }\end{array}$ & Country & $\begin{array}{c}\text { Study } \\
\text { design }\end{array}$ & Sample & \begin{tabular}{|c|c|} 
Methodology \\
used
\end{tabular} & Main results \\
\hline $\begin{array}{l}\text { Register et } \\
\text { al. }(2000)\end{array}$ & USA & $\begin{array}{l}\text { Descriptive } \\
\text { study }\end{array}$ & $\begin{array}{l}12 \text { medical office } \\
\text { assistants, } 23 \\
\text { licensed practical } \\
\text { nurses and } 99 \\
\text { nurses }\end{array}$ & $\begin{array}{l}\text { Questionnaire } \\
\text { with } 42 \text { items }\end{array}$ & $\begin{array}{l}58 \% \text { agreed or strongly agreed that exclusive } \\
\text { breastfeeding is a beneficial form of nutrition. 35\% } \\
\text { agreed or strongly agreed with the statement that } \\
\text { supplementing breastfeeding with formula during } \\
\text { the first } 2 \text { weeks of life is a cause of breastfeeding } \\
\text { failure }\end{array}$ \\
\hline $\begin{array}{l}\text { Meaux et al. } \\
\text { (1999) }\end{array}$ & $\begin{array}{l}\text { Puerto } \\
\text { Rico }\end{array}$ & $\begin{array}{l}\text { Exploratory } \\
\text { study }\end{array}$ & $\begin{array}{l}29 \text { pediatrics } 26 \\
\text { gynecology and } \\
\text { obstetrics }\end{array}$ & Questionnaire & $\begin{array}{l}27.8 \% \text { of doctors would recommend a combination } \\
\text { of natural and artificial breastfeeding for mothers } \\
\text { who are lactating but are concerned about milk } \\
\text { production during the first two weeks of birth. } \\
\text { While } 64.8 \% \text { would recommend exclusive } \\
\text { breastfeeding. } 63.6 \% \text { of doctors recommend } \\
\text { complete weaning in cases of abscess and } 30.9 \% \text { in } \\
\text { cases of mastitis. In addition, when there is diarrhea, } \\
\text { significantly more with obstetricians ( } 26.9 \%) \text { than } \\
\text { pediatricians are (3.4\%). } 100 \% \text { of obstetricians and } \\
96.2 \% \text { of pediatricians do not recommend weaning } \\
\text { when the eruption begins }\end{array}$ \\
\hline $\begin{array}{l}\text { Burglehaus } \\
\text { et al. (1997) }\end{array}$ & England & $\begin{array}{l}\text { Cross- } \\
\text { sectional } \\
\text { study }\end{array}$ & $\begin{array}{l}24 \text { obstetricians; } \\
20 \text { pediatricians; } \\
69 \text { family } \\
\text { practitioners; } \\
97 \text { general } \\
\text { practitioners }\end{array}$ & $\begin{array}{l}\text { Questionnaire } \\
\text { with } 40 \\
\text { questions }\end{array}$ & $\begin{array}{l}\text { In the face of breastfeeding problems, } 94 \% \text { of } \\
\text { doctors reportedly always or usually encourage } \\
\text { patients to continue breastfeeding. Family } \\
\text { practitioners more strongly believed that } \\
\text { breastfeeding provides adequate nutrition than did } \\
\text { doctors in other specialties and general practitioners } \\
\text { were more likely to be neutral or disagree. } 24 \% \text { of } \\
\text { doctors felt that adding cereals to the infant's diet } \\
\text { helps the infant sleep through the night }\end{array}$ \\
\hline $\begin{array}{l}\text { Patton et al. } \\
\text { (1996) }\end{array}$ & USA & $\begin{array}{l}\text { Cross- } \\
\text { sectional } \\
\text { study }\end{array}$ & 230 nurses & $\begin{array}{l}\text { Questionnaire } \\
\text { with } 19 \\
\text { questions }\end{array}$ & $\begin{array}{l}64 \% \text { of the nurses indicated they were very } \\
\text { interested in helping mothers learn how to } \\
\text { breastfeed and would encourage breastfeeding. } \\
75 \% \text { nurses classified the time factor as primary } \\
\text { nursing barriers to breastfeeding promotion. } \\
64 \% \text { of nurses mentioned that the most common } \\
\text { form of breastfeeding information sources was } \\
\text { their personal experience with breastfeeding. The } \\
\text { most common maternal barriers to breastfeeding } \\
\text { mentioned by nurses were incomplete knowledge } \\
\text { and psychological support }\end{array}$ \\
\hline $\begin{array}{l}\text { Lazzaro et } \\
\text { al. (1995) }\end{array}$ & USA & $\begin{array}{l}\text { Cross- } \\
\text { sectional } \\
\text { study }\end{array}$ & $\begin{array}{l}151 \text { HPs } \\
\text { (doctors, nurses, } \\
\text { licensed practical } \\
\text { nurses, medical } \\
\text { assistants, and } \\
\text { nutritionists) }\end{array}$ & $\begin{array}{l}\text { Questionnaire } \\
\text { with } 17 \\
\text { questions }\end{array}$ & $\begin{array}{l}91 \% \text { of the doctors and } 92 \% \text { of the nurses in private } \\
\text { offices advocate breastfeeding when a mother is } \\
\text { undecided about infant feeding. All categories of } \\
\text { professionals recommend giving supplements to } \\
\text { breastfed infants. } 81.7 \% \text { agreed with the statement } \\
\text { that supplementation with formula in the first } \\
2 \text { weeks of life is a cause of breastfeeding failure. } \\
\text { Between } 87-100 \% \text { of respondents rated the mother's } \\
\text { return to work or school as more important than } \\
\text { other reasons for early cessation of breastfeeding, } \\
\text { such as baby teething }\end{array}$ \\
\hline
\end{tabular}


Chart 2. Description of the included studies.

\begin{tabular}{|c|c|c|c|c|c|}
\hline $\begin{array}{c}\text { Author } \\
\text { (year) }\end{array}$ & Country & $\begin{array}{l}\text { Study } \\
\text { design }\end{array}$ & Sample & $\begin{array}{c}\text { Methodology } \\
\text { used }\end{array}$ & Main results \\
\hline $\begin{array}{l}\text { Barnett, } \\
\text { Sienkiewicz } \\
\text { and Roholt } \\
(1995)\end{array}$ & USA & $\begin{array}{l}\text { Cross- } \\
\text { sectional } \\
\text { Study }\end{array}$ & $\begin{array}{l}1754 \text { nurses; } 135 \\
\text { nutritionists; } 135 \\
\text { pediatricians; } 65 \\
\text { family doctors; } \\
55 \text { obstetricians; } \\
65 \text { health } \\
\text { educators }\end{array}$ & $\begin{array}{l}\text { Questionnaire } \\
\text { with } 10 \text { belief } \\
\text { statements }\end{array}$ & $\begin{array}{l}80 \% \text { of health professionals strongly disagreed that } \\
\text { most breastfeeding babies require supplemental } \\
\text { formula to gain sufficient weight. Only } 14 \% \text { of } \\
\text { professionals with somewhat negative beliefs } \\
\text { advocated weaning at } 2 \text { years of age or older, } \\
\text { compared with } 24 \text { percent of those with somewhat } \\
\text { positive beliefs and } 47 \text { percent with positive beliefs. } \\
\text { Breastfeeding beliefs, work environment, and } \\
\text { personal breastfeeding experience each significantly } \\
\text { influenced advocacy of early weaning from the } \\
\text { breast, defined as } 9 \text { months of age or younger }\end{array}$ \\
\hline $\begin{array}{l}\text { Bagwell et } \\
\text { al. (1993) }\end{array}$ & USA & $\begin{array}{l}\text { Cross- } \\
\text { sectional } \\
\text { Study }\end{array}$ & $\begin{array}{l}41 \text { nutritionists, } \\
158 \text { nurses and } \\
90 \text { doctors }\end{array}$ & Questionnaire & $\begin{array}{l}\text { HPs were slightly less likely to recommend } \\
\text { breastfeeding to working mothers, mothers in } \\
\text { school, and adolescent mothers. They did not } \\
\text { recommend breastfeeding for mentally retarded } \\
\text { mothers. nutritionists and nurses were more likely } \\
\text { to recommend breastfeeding to a mother who had } \\
\text { made the decision to bottle-feed than were doctors. } \\
\text { Doctors were less likely to think that breastfeeding } \\
\text { was incompatible with working outside the home } \\
\text { or attending school than were nurses. nutritionists } \\
\text { were more interested in breastfeeding and lactation } \\
\text { management than were nurses. Nurses were more } \\
\text { likely than dietitians and doctors to think that } \\
\text { mastitis and engorgement are reasons to discontinue } \\
\text { breastfeeding }\end{array}$ \\
\hline $\begin{array}{l}\text { Hull, } \\
\text { Thapa and } \\
\text { Wiknjosastro } \\
\text { (1989) }\end{array}$ & Indonesia & $\begin{array}{l}\text { Cross- } \\
\text { sectional } \\
\text { study }\end{array}$ & $\begin{array}{l}111 \text { midwifes; } 26 \\
\text { nurses; } 12 \text { general } \\
\text { practitioners; } \\
11 \text { obstetrician/ } \\
\text { gynecologist; } 7 \\
\text { pediatricians }\end{array}$ & Questionnaire & $\begin{array}{l}50 \% \text { of health providers thought that exclusive } \\
\text { breastfeeding was sufficient for only } 3 \text { months and } \\
\text { a further } 16 \% \text { for only } 2 \text { months. Most respondents } \\
\text { felt that solid food should be introduced at } 3-4 \\
\text { months of age. } 68 \% \text { of health providers felt that a } \\
\text { baby with diarrhea should still be breastfed }\end{array}$ \\
\hline $\begin{array}{l}\text { Popkin, } \\
\text { Yamamoto } \\
\text { and Griffin } \\
(1984)\end{array}$ & USA & $\begin{array}{l}\text { Cross- } \\
\text { sectional } \\
\text { study }\end{array}$ & $\begin{array}{l}189 \text { doctors, } \\
280 \text { nurses, } 782 \\
\text { midwives, } 47 \\
\text { health aides }\end{array}$ & Questionnaire & $\begin{array}{l}\text { More than } 70 \% \text { of the professionals contraindicated } \\
\text { the continuation of breastfeeding in the following } \\
\text { situations: breast abscess, mothers with tuberculosis } \\
\text { and babies with diarrhea }\end{array}$ \\
\hline
\end{tabular}

HPs: health professionals. HIV: human immunodeficiency virus. WIC personnel: these are usually for nutrition assistants, clerks, breastfeeding peer counselors, dietitians, nutritionists and custodians. WHO: World Health Organization.

Source: Authors.

The duration of exclusive breastfeeding was investigated by eleven studies. A high level of recommendation was reported by two authors, reaching more than $90 \%$ of participants who recommended exclusive breastfeeding until to six months ${ }^{27,29}$. Regular level of recommendation was found in four studies, where the recommendation up to six months ranged from $49 \%$ to $61 \%$ among professionals ${ }^{30-33}$. In five studies, a low knowledge level about the time of exclusive breastfeeding was observed ${ }^{22,26,34-36}$ where the percentage reached up to $61 \%$ of error in the recommendation $^{36}$.

Eight studies assessed knowledge about the duration of breastfeeding. Of these, three reported a high knowledge level of the sample with a recommendation level for breastfeeding continuation up to 24 months by $70 \%{ }^{26}, 83.1 \%{ }^{29}$ and $84.8 \%{ }^{27}$ of the professionals, respectively. The other four studies reported a low knowledge level about breastfeeding time ${ }^{21,22,31,36,37}$, where $66 \%$ of the sample did not recommend that it would be 
performed until 12 months $^{36}$ and almost half of another sample (45\%) did not agree or were not sure about that time ${ }^{21}$.

The reasons cited by the professionals to stop breastfeeding or does not recommend its performance were related to mothers, such as: breast abscess $^{13,38,39}$, mastitis ${ }^{13,32,39,40}$, HIV infection ${ }^{32,33,36}$, active tuberculosis ${ }^{33,38}$, cracked nipples $^{32,41}$, hepatitis $\mathrm{B}^{32,33}$, hepatitis $\mathrm{C}^{32,33}$, working mothers ${ }^{30,37,40}$, student mothers ${ }^{40}$, teenage mothers ${ }^{16,40}$, mental retardation ${ }^{40}$, maternal fatigue ${ }^{21}$, use of illicit drugs $^{32}$ and lack of breast milk ${ }^{30}$. The reasons related to babies were: baby's diarrhea ${ }^{13,38,39,41}$, child's galactosemia ${ }^{32,33}$, child's jaundice ${ }^{32}$, engorgement ${ }^{40}$, biting while breastfeeding ${ }^{22}$, dehydration up to three days after delivery ${ }^{42}$, baby seems to be hungry ${ }^{42}$, insufficient weight gain for babies ${ }^{30}$ and premature babies or low birth weight ${ }^{30}$.

In two studies ${ }^{43,44}$ the professionals pointed out causes that can influence early weaning, such as: maternal mental health conditions, breast surgeries, prescribed medications, social situations, socioeconomic conditions, return to work $^{43}$, families that were not well informed, families that prefer a formula, a nurse's recommendation, a nursing team that did not encourage breastfeeding, a neonatologist's recommendation, doctors that do not encourage breastfeeding and inadequate lactation consultation ${ }^{44}$.

The barriers highlighted by health professionals to promote breastfeeding were: lack of knowledge and psychological support to moth$\mathrm{ers}^{45}$, lack of professional time ${ }^{33,45}$, need for training, being comfortable to guide mothers only when they asked, and they do not believe that they can influence the mother ${ }^{33}$.

\section{Discussion}

Breastfeeding is a natural process of mammals that has health and psychological benefits for both mother and baby ${ }^{2}$. As evidenced by our results, most professionals are familiar with these benefits $^{19,21-23,27,28,32}$. However, according to the World Health Organization (WHO), almost two out of three babies are not exclusively breastfed until the age of six months, a fact that has not improved in decades ${ }^{46}$.

The economic benefit of breastfeeding was highlighted among the health professionals who participated in the reviewed studies ${ }^{19,22,28}$, being considered the cheapest way to feed a baby. Despite this benefit, Melin, Björklund and Zwed- berg $^{43}$ reported that doctors believed that one of the factors related to the mothers' decision not to breastfeed or stop after a few months would be the socioeconomic condition, since low-income countries have lower rates of breastfeeding. This behavior contradicts the findings of a major literature reviewed that states that, with a few exceptions, the duration of breastfeeding in high-income countries is shorter compared to low-income countries ${ }^{47}$.

In our results, many professionals agree that they play an important role in the approach of breastfeeding ${ }^{43,44}$ and that they act directly in this process helping with breastfeeding techniques, advice on infant feeding methods ${ }^{19}$, prenatal counseling and lactation problems ${ }^{13}$. However, professionals report that they receive guidelines about the benefits of breastfeeding during their courses, but practical training on breastfeeding techniques is insufficient ${ }^{32}$. Melin, Björklund and Zwedberg ${ }^{43}$ highlight that courses are concerned with the type of baby's nutrition and not with the practical of breastfeeding itself. Thus, health professionals reported having acquired their knowledge about the practical of breastfeeding with professionals different from their own area $^{45}$, or through their own experience as mothers or still through the observation of mothers in the community that they live or work ${ }^{25}$, and also through lectures ${ }^{15}$.

It is important to report that attitudes and practices about breastfeeding and weaning were not actually evaluated in the present study, as there were no studies that assessed such outcomes, which could be a limitation. This was the reason why the keywords "attitudes" and "practice" appears in the search strategy, but nothing is presented about this issue.

Two studies show that the level of professional qualification influences the knowledge about breastfeeding of health professionals, where professionals with higher educational background had a higher rate of knowledge than those with less education ${ }^{14,41}$. In our work, studies with graduated and non-graduated professionals were included. Thus, we do not believe that this factor has negatively influenced our results, as some professionals included in the samples of the selected studies did not graduate from universities, but receive specific training for breastfeeding and breast milk ${ }^{23,27}$. However, most of the studies included in our review have a sample of graduated professionals.

Another factor that influenced the level of knowledge of professionals was personal experi- 
ence. However, this personal experience should be interpreted with caution, as demonstrated by Szucs et al. ${ }^{17}$, who affirmed that personal experience of health professionals referring to breastfeeding may be related to recommendations contrary to the evidence-based recommendations. In addition, Xian et al. ${ }^{14}$, highlighted that health professionals who were parents of children up to two years old had more knowledge about breastfeeding than professionals who did not have children. Also, Svendby et al. ${ }^{36}$ reported that female professionals had more knowledge than male professionals.

When comparing the knowledge of different professionals, one study related that the knowledge of doctors was lower than those of nutritionists, midwives and nurses ${ }^{18}$. However, in another evaluation ${ }^{40}$, they did not show scores that were statistically different from those of nutritionists or nurses. Although they reported being able to manage medical problems such as mastitis, doctors reported delegating the responsibility of providing practical breastfeeding support to lactation consultants ${ }^{22}$ and midwives ${ }^{43}$. Therefore, there is a need to improve multiprofessional work and communication between the groups involved with breastfeeding, highlighting that they should receive mutual learning ${ }^{43}$.

Considering the breastfeeding time, the WHO recommends exclusive breastfeeding for the first six months of life, followed by breastfeeding associated with adequate complementary food for up to two years or more ${ }^{48}$. It is known that exclusive breastfeeding is the best source of protection and nutrition for the baby up to the sixth month of life, with no other type of food or liquid necessary ${ }^{49}$. However, our results show that knowledge about exclusive breastfeeding for up to six months is not satisfactory $\mathrm{y}^{22,26,31,34-36}$. It has been shown that doctors and nurses recommended that mothers give liquids and solid foods to babies under six months of age ${ }^{31}$.

Even though the WHO recommendation is not current ${ }^{48}$, our results demonstrate that there is a lack of knowledge among professionals regarding the duration of breastfeeding. Levinien et al. ${ }^{31}$ reported that the most of general practitioners and nurses did not know that breastfeeding with complementary foods should be continued until two years of age or older. In addition, more recent studies have cited that general practitioners have demonstrated negative opinions about breastfeeding up to twenty-four months ${ }^{22}$ and almost half have recommended that children be breastfed up to twelve months ${ }^{36}$. It is worth mentioning that one of the studies ${ }^{22}$ was carried out in Australia where the national health and medical research council recognizes the continuation of breastfeeding for at least twelve months, which can cause confusion regarding the professionals' guidelines and is not according to the guidelines established by the WHO.

A review of the previous literature evaluating studies with nursing mothers highlighted the factors that make breastfeeding difficult and cause early weaning, which could be: the perception of weak or insufficient milk, use of a pacifier, return to work or school, nipple fissure and pain, lack of encouragement from health professionals for exclusive breastfeeding, precarious knowledge of mothers about the importance of breastfeeding, low level of education of the mother and increasing the child's age ${ }^{49}$. In our results, we observed that many professionals reported at least one of these situations as a factor for not indicating or not encouraging breastfeeding $30,32,37,40,41$. However, these studies were carried out more than ten years ago and what makes us believe that a change in the knowledge regarding factors such as weak milk, nipple fissure and returning to work or school is happening. Despite this, the lack of maternal knowledge and the lack of encouragement from health professionals reported by mothers demonstrates their direct influence on the success of breastfeeding, as observed by Sims et al. ${ }^{44}$.

Our results demonstrated a conflict of knowledge related to weaning and beginning of deciduous dentition. McLaughlin et al. ${ }^{21}$ and Pereda et al. ${ }^{39}$ reported that doctors and nurses do not recommend weaning when the rash starts. However, Holtzman and Usherwood ${ }^{22}$ reported that a doctor stated he recommends that mothers wean if the baby bites while breastfeeding. The American Academy of Pediatric Dentistry (AAPD) recommends that children should be taken to the pediatric dentist at no later than your child's first birthday or when the time of the eruption of the first tooth ${ }^{50}$. This is an opportune time for the dentist to provide guidance on the benefits of breastfeeding, the correct weaning protocol and appropriate oral hygiene guidelines. It is known that oral health is an integral part of the general health and that child's general health care cannot be achieved if oral care is not included ${ }^{51}$. Despite that, none of the selected studies evaluated the knowledge of dentists about breastfeeding and weaning. That is, after the systematic search in each electronic base, none of the studies included dentists as part of the sample. Thus, it represents 
a warning sign for dentists, which suggests that they are not considered by many to be professionals who work directly with such themes in their clinical practices.

An important habit reported in our results and the dentist's technical competence is the use of pacifiers. The use of pacifiers can cause a decrease in the frequency of feedings, reduced stimulation, and withdrawal of breast milk, which leads to less milk production, and consequently to weaning ${ }^{52}$. In addition, non-nutritive sucking habits, such as the use of pacifiers, can negatively affect the orofacial system. Scientific evidence has shown an association between the use of pacifiers and the presence of anterior open bite and posterior cross bite. So-called orthodontic pacifiers reduce the prevalence of open bite when compared to non-orthodontic pacifiers; however, it is not possible to state that orthodontic pacifiers show a positive effect on crossbite ${ }^{53}$. In our results, opinions about the use of pacifiers were contradictory, Levinien et al. ${ }^{31}$, Silvestre et al. ${ }^{29}$ and Fonseca-Machado et al. ${ }^{42}$ agree that pacifiers should not be recommended as it can negatively affect breastfeeding. However, more than a half of the nurses assessed by McLaughlim et al. ${ }^{21}$ did not know that pacifiers can cause confusion in babies who are starting the breastfeeding. In addition, Szucs, Miracle and Rosenman ${ }^{17}$ reported that some professionals advise the early use of pacifiers. These counterpoints once again demonstrate the importance of including all health professionals, involving dentists, in child health promotion programs and research on breastfeeding and weaning.

As previously highlighted, breastfeeding plays an important role in child health. In this sense, it has an extremely importance for the development of a normal dental occlusion. Studies have shown a lower proportion of malocclusion in primary dentition in children breastfed up to 12 month $s^{54}$ or more ${ }^{55}$, regardless the sociodemographic factors. Another advantage of natural breastfeeding clarified in the recent years is that breast milk alone does not cause a decrease in the biofilm $\mathrm{pH}$, suggesting that breastfeeding alone may not contribute to early childhood caries ${ }^{56}$. In addition, a systematic review suggests that children breastfed exclusively for up to 12 months compared to those breastfed for less time were protected from tooth decay ${ }^{57}$. Thus, we emphasize the importance of pediatric dentistry in the care of newborns, so that risk assessments of early childhood caries should be carried out, as well as the diagnosis and early intervention of malocclusions.

Health education can be considered a process that induces behavioral change related to health, not only individual, but also collective ${ }^{58}$. Given the importance of the dentist highlighted here earlier, the rapprochement between pregnant women/infants and a multiprofessional health team including dentists appears to be a fundamental challenge for the beginning of a promising oral health promotion cycle for women and babies. It is essential to rethink the formation of an interprofessional prenatal work team ${ }^{59}$. In this context, the dentist may be part of this team, being responsible for the development of oral health education actions, where women can become aware of their important role in the acquisition of positive oral health habits and their maintenance, acting as an information multiplying agent ${ }^{60}$. In addition, dentists in a pre-natal team would welcome and support breastfeeding, highlighting its importance for the development of the stomatognathic system ${ }^{7}$.

The need and lack of specific training on breastfeeding were reported by the authors ${ }^{23,25}$ and observed in our study. We believe that this factor may have influenced the low level of knowledge of professionals, especially regarding the time and management of practical problems that may occur during the breastfeeding period. Thus, the importance of implementing breastfeeding promotion programs during the training of health professionals and effective policies to promote child health is highlighted. In addition, we emphasize the inclusion of the dentist in this context as a fundamental part of promoting the child's comprehensive health.

\section{Conclusion}

This scope review shows that health professionals with different formations are aware of the benefits of breastfeeding for the mother and the baby. However, these issues have conflicting knowledge about the exclusive breastfeeding time and the duration of breastfeeding. Moreover, despite the knowledge of the main reasons that may lead to early weaning, many professionals are trapped in barriers to promote breastfeeding. 


\section{Collaborations}

MLD conduct the review, drafted, and wrote down the manuscript. Also searched the databases, evaluated the articles, collected the data and approved the version to be published; KRD carried out searches in the databases, evaluated the articles and approved the version to be published; DMTPF, a librarian experienced in systematic searches, guided the search strategy and approved the version to be published; AFG idealized the study design, critically reviewed the manuscript and approved the version to be published.

\section{Acknowledgments}

We are grateful to the Fundação de Amparo à Pesquisa do Estado do Rio de Janeiro (FAPERJ) and the Coordenação de Aperfeiçoamento de Pessoal de Nível Superior (CAPES) for granting the doctoral scholarships to the first and second authors respectively.

\section{References}

1. Cunniff A, Spatz D. Mothers' Weaning Practices When Infants Breastfeed for More Than One Year. MCN Am J Matern Child Nurs 2017; 42(2):88-94.

2. Gertosio C, Meazza C, Pagani S, Bozzola M. Breastfeeding and its gamut of benefits. Minerva Pediatr 2016; 68(3):201-212.

3. Greiner T. The Concept of Weaning: Definitions and Their Implications. J Hum Lact 1996; 12(2):123-128.

4. Sellen DW, Smay DB. Relationship between subsistence and age at weaning in "preindustrial" societies. Hum Nat 2001; 12(1):47-87.

5. World Health Organization (WHO). Complementary feeding: report of the global consultation, and summary of guiding principles for complementary feeding of the breastfed child. WHO; 2002. [cited 2020 Jun 4]. Available from: https://apps.who.int/iris/ handle/10665/42739

6. World Health Organization (WHO). Ten steps to successful breastfeeding. [cited 2020 Jun 02]. Available at: http://www.who.int/nutrition/bfhi/ten-steps/en/

7. Antunes LS, Antunes LAA, Corvino MPF, Maia LC. Breast-feeding as a source of prevention in healthcare. Cien Saude Colet 2008; 13(1):103-109.

8. Askey H, O'Malley L. Scoping Studies: Towards a Methodological Framework. Int J Soc Res Methodol 2005; 8(1):19-32.

9. Levac D, Colquhoun H, O'Brien KK. Scoping studies: advancing the methodology. Implement Sci 2010; 5:69.

10. Tricco AC, Lillie E, Zarin W, O’Brien KK, Colquhoun H, Levac D, Moher D, Peters MDJ, Horsley T, Weeks L, Hempel S, Akl EA, Chang C, McGowan J, Stewart L, Hartling L, Aldcroft A, Wilson MG, Garritty C, Lewin S, Godfrey CM, Macdonald MT, Langlois EV, Soares -Weiser K, Moriarty J, Clifford T, Tunçalp Ö, Straus SE. PRISMA extension for scoping reviews (PRISMA-ScR): checklist and explanation. Ann Intern Med 2018; 169(7):467-473.

11. Hellings P1, Howe C. Breastfeeding knowledge and practice of pediatric nurse practitioners. J Pediatr $\mathrm{He}$ alth Care 2004; 18(1):8-14

12. Sallam SA, Babrs GM, Sadek RR, Mostafa AM. Knowledge, Attitude, and Practices Regarding Early Start of Breastfeeding Among Pregnant, Lactating Women and Healthcare Workers in El-Minia University Hospital. Breastfeed Med 2013; 8(3):312-316.

13. Alakaam A, Lemacks J, Yadrick K, Connell C, Choi HW, Newman RG. Maternity Nurses' Knowledge and Practice of Breastfeeding in Mississippi. MCN Am J Matern Child Nurs 2018; 43(4):225-230.

14. Xian S, Yue Z, Weiwei F, Lixia C, Xi J, Huishan W, Meijing A, Yanping X. [Research on Knowledge Status and Relevant Factors of Breastfeeding Among Medical Staff in China Based on Network Platform]. [article in Chinese]. Zhonghua Yu Fang Yi Xue Za Zhi 2019; 53(11):1170-1173.

15. Al-Nassaj HH, Al-Ward NJA, Al-Awqati NA. Knowledge, Attitudes and Sources of Information on Breast Feeding Among Medical Professionals in Baghdad. East Mediterr Health J 2004; 10(6):871-878.

16. Spear HJ. Nurses' attitudes, knowledge, and beliefs related to the promotion of breastfeeding among women who bear children during adolescence. J Pediatr Nurs 2004; 19(3):176-183. 
17. Szucs KA, Miracle DJ, Rosenman MB. Breastfeeding Knowledge, Attitudes, and Practices Among Providers in a Medical Home. Breastfeed Med 2009; 4(1):31-42.

18. Marambio LM, Benadof D, Huerta CT. Breastfeeding Knowledge of Health Professionals Working in $\mathrm{Mu}-$ nicipal Healthcare Centers in Maipu, Chile. Medwave 2017; 17(3):e6891.

19. Lazzaro E, Anderson J, Auld G. Medical professionals' attitudes toward breastfeeding. J Hum Lact 1995; 11(2):97-101.

20. Burglehaus MJ, Smith LA, Sheps SB, Green LW. Physicians and breastfeeding: beliefs, knowledge, self-efficacy and counselling practices. Can J Public Health 1997; 88(6):383-387.

21. McLaughlin M, Fraser J, Young J, Keogh S. Paediatric nurses' knowledge and attitudes related to breastfeeding and the hospitalised infant. Breastfeed Rev 2011; 19(3):13-24.

22. Holtzman O, Usherwood T. Australian general practitioners' knowledge, attitudes and practices towards breastfeeding. PLoS One 2018; 13(2):e0191854.

23. Register N1, Eren M, Lowdermilk D, Hammond R, Tully MR. Knowledge and attitudes of pediatric office nursing staff about breastfeeding. J Hum Lact 2000; 16(3):210-215.

24. Hellings P, Howe C. Breastfeeding knowledge and practice of pediatric nurse practitioners. J Pediatr Health Care 2004; 18(1):8-14.

25. Marques ES, Cotta RMM, Franceschini SCC, Botelho MIV, Araújo RMA, Junqueira TS. Práticas e percepções do aleitamento materno: consensos e disssensos no cotidiano de cuidado numa Unidade de Saúde da Família. Rev Saude Colet 2009; 19(2):439-455.

26. Hanif R, Khalil E, Sheikh A, Harji A, Haris S, Rasheed MW, Ahmed S, Abdul Aziz K, Shaheen E, Younus A, Mansoor M, Hameed F, Touseef M, Yaseen T. Knowledge about breastfeeding in accordance with the national policy among doctors, paramedics and mothers in baby-friendly hospitals. J Pak Med Assoc 2010; 60(10):881-886.

27. Artantas $A B$, Tetis BK, Kilıc M, Eray IK, Cetin N, Güney S, Akdogan D, Domad U, Ustu Y, Ugurlu M. [Knowledge Level, Attitude and Own Experience of Health Professionals About Breastfeeding and Breast Milk in a City of Turkey: Cross-sectional Study]. [article in English, Spanish]. Arch Argent Pediatr 2016; 114(6):514-520.

28. Dias RB, Boery RN, Vilela AB. [Knowledge of nurses and incentive strategies for family participation in breastfeeding]. [article in Portuguese]. Cien Saude Colet 2016; 21(8):2527-36.

29. Silvestre PK, Carvalhaes MA, Venâncio SI, Tonete VL, Parada CM. Breastfeeding knowledge and practice of health professionals in public health care services. Rev Lat Am Enfermagem 2009; 17(6):953-960.

30. Karaçam Z, Kiti Y. What Do Midwives and Nurses in Turkey Know About Nutrition in the First Six Months of Life. Midwifery 2005; 21(1):61-70.

31. Leviniene G, Petrauskiene A, Tamuleviciene E, Kudzyte J, Labanauskas L. The evaluation of knowledge and activities of primary health care professionals in promoting breast-feeding. Medicina (Kaunas) 2009; 45(3):238-247.
32. Leavitt G, Martínez S, Ortiz N, García L. Knowledge About Breastfeeding Among a Group of Primary Care Physicians and Residents in Puerto Rico. J Community Health 2009; 34(1):1-5.

33. Schaffar A, Huyghe A-S, Bomy H, Duriez P, Ego A, Pierrat V. [Breastfeeding: Opinion and Knowledge of Pharmacists. A Study in a Semi-Urban Territory] [Article in French]. Arch Pediatr 2012; 19(5):476-483.

34. Hull VJ, Thapa S, Wiknjosastro G. Breast-feeding and health professionals: a study in hospitals in Indonesia. Soc Sci Med 1989; 28(4):355-364.

35. Okolo SN, Ogbonna C. Knowledge, Attitude and Practice of Health Workers in Keffi Local Government Hospitals Regarding Baby-Friendly Hospital Initiative (BFHI) Practices. Eur J Clin Nutr 2002; 56(5):438-441.

36. Svendby HR, Løland BF, Omtvedt M, Holmsen ST, Lagerløv P. Norwegian General Practitioners' Knowledge and Beliefs About Breastfeeding, and Their Self-Rated Ability as Breastfeeding Counsellor. Scand J Prim Health Care 2016; 34(2):122-129.

37. Barnett E, Sienkiewicz M, Roholt S. Beliefs About Breastfeeding: A Statewide Survey of Health Professionals. Birth 1995; 22(1):15-20.

38. Popkin BM, Yamamoto ME, Griffin CC. Traditional and Modern Health Professionals and Breast-feeding in the Philippines. J Pedriatr Gastroenterol Nutr 1984; 3(5):765-776.

39. Pereda LM, Torres RRD, Pérez JA, Rodríguez AMP. [Gynecologists-obstetricians and Pediatricians: Knowledge and Experience Concerning Breast Feeding] [Article in Spanish]. P R Health Sci J 1999; 18(3):251-256.

40. Bagwell JE, Kendrick OW, Stitt KR, Leeper JD. Knowledge and Attitudes Toward Breast-Feeding: Differences Among Dietitians, Nurses, and Physicians Working with WIC Clients. J Am Diet Assoc 1993; 93(7):801-804.

41. Rasheed S, Siddiqui I, Baig LA. Decline in Breast Feeding, Who Is to Be Blamed?!! A Study of Knowledge, Attitude and Practice of Breast Feeding Amongst Nurses. J Pak Med Assoc 2000; 50(1):8-11.

42. Fonseca-Machado Mde O, Haas VJ, Monteiro JC, Gomes-Sponholz F. Continuing education in nursing as a factor associated with knowledge on breastfeeding. Invest Educ Enferm 2014; 32(1):139-147.

43. Melin A, Björklund P, Zwedberg S. Pediatricians' Experiences of Working with Breastfeeding: An Interview Study. Sex Reprod Healthc 2018; 16:218-223.

44. Sims AM, Long SA, Tender JAF, Young MA. Surveying the Knowledge, Attitudes, and Practices of District of Columbia ACOG Members Related to Breastfeeding. Breastfeed Med 2015; 10(1):63-68.

45. Patton CB, Beaman M, Csar N, Lewinski. Nurses' Attitudes and Behaviors that Promote Breastfeeding. $J$ Hum Lact 1996; 12(2):111-115.

46. World Health Organization (WHO). Health topics: Breastfeeding. [cited 2020 Jun 02]. Available at: https://www.who.int/health-topics/breastfeeding\#tab=tab_1

47. Victora CG, Bahl R, Barros RJD, França GVA, Horton S, Krasevec J, Murch S, Sankar MJ, Walker N, Rollins NC. Breastfeeding in the 21st Century: Epidemiology, Mechanisms, and Lifelong Effect. Lancet 2016; 387(10017):475-490. 
48. World Health Organization (WHO). Global strategy for infant and young child feeding. Fifty-Fourth World Health Assembly. Geneva: WHO; 2003. [cited 2020 Jun 4]. Available at: http://apps.who.int/iris/bitstream/10665/42590/1/9241562218.pdf.

49. Lima APC, Nascimento DS, Martins MMF. The practice of breastfeeding and the factors that take to early weaning: an integrating review. J Health Biol Sci 2018; 6(2):189-196.

50. American Academy of Pediatric Dentistry (AAPD). A National Children's Dental Health Month Letter from AAPD President Dr. Donly. [cited 2020 Jun 02]. Available at: https://www.aapd.org/about/about-aapd/ news-room/latest-news/a-national-childrens-dental -health-month-letter-from-aapd-president-dr.-donly/

51. American Academy of Pediatric Dentistry (AAPD). Policy on Oral Health Care Programs for Infants, Children, and Adolescents. The Reference Manual of Pediatric Dentistry. Pediatr Dent 2019-2020; p. 32-33.

52. Sertório SCM, Silva IA. As faces simbólicas e utilitária da chupeta na visão de mães. Rev Saúde Pública 2005; 39(2):156-162.

53. Schmid KM, Kugler R, Nalabothu P, Bosch C, Verna C. The Effect of Pacifier Sucking on Orofacial Structures: A Systematic Literature Review. Prog Orthod 2018; 19(1):8.

54. Corrêa-Faria P, de Abreu MHNG, Jordão LMR, Freire MCM, Costa LR. Association of Breastfeeding and Malocclusion in 5-year-old Children: Multilevel Approach. Int J Paediatr Dent 2018; 28(6):602-607.

55. Peres KG, Chaffee BW, Feldens CA, Flores-Mir C, Moynihan P, Rugg-Gunn A. Breastfeeding and Oral Health: Evidence and Methodological Challenges. $J$ Dent Res 2018; 97(3):251-258.

56. Neves PAM, Ribeiro CCC, Tenuta LMA, Leitão TJ, Monteiro-Neto V, Nunes AMM, Cury JA. Breastfeeding, Dental Biofilm Acidogenicity, and Early Childhood Caries. Caries Res 2016; 50:319-324.

57. Tham R, Bowatte G, Dharmage SC, Tan DJ, Lau ZXM, Dai X, Allen KJ, Lodge CJ. Breastfeeding and the Risk of Dental Caries: A Systematic Review and Meta-Analysis. Acta Paediatr 2015; 104(467):62-84

58. Miranda J, Lemos M, Torres M, Sovieiro V, Cruz R. Promoção de saúde bucal em odontologia: uma questão de conhecimento e motivação. Rev do CROMG 2000; 6(3):154-157.

59. Finkler M, Oleiniski DMB, Ramos FRS. Pregnancy and Oral Health: a Social Representation Study. Texto Contexto Enferm 2004; 13(3):360-368.

60. Reis DM, Pitta DR, Ferreira HMB, de Jesus MCP, de Moraes MEL, Soares MG. Health education as a strategy for the promotion of oral health in the pregnancy period. Cien Saude Colet 2010; 15(1):269-276.

Article submitted 09/06/2020

Approved 07/01/2021

Final version submitted 09/01/2021

Chief editors: Romeu Gomes, Antônio Augusto Moura da Silva 
